\title{
Overview of Public Services at the One-Stop Investment and Integrated Service Office of South Sulawesi
}

\author{
Aris Baharuddin \\ Universitas Negeri Makassar \\ E-mail: aris.baharuddin@yahoo.com
}

\begin{abstract}
Basically, humans need service, the concept of this service will always be in the life of every human being. This study aims to determine tangibles, reliability, responsiveness, assurance, and empathy in public services at DPMPTSP South Sulawesi. This study uses a qualitative approach to the type of descriptive analysis research with data collection techniques namely observation, in-depth interviews, and documentation. Data analysis techniques used are data reduction, data presentation, and drawing conclusions. The results showed that the implementation of public services carried out at DPMPTSP South Sulawesi held well, as evidenced by the application of the green zone from Ombudsman
\end{abstract}

Keywords: Implementation, public service, one-stop service

\section{INTRODUCTION}

Public services have now become a central issue in development in Indonesia. The development of public services is always actual to be discussed. Basically, humans need service, the concept of this service will always be in the life of every human being. The position of the people who turn into citizens makes the public service providers not only position the community as consumers but furthermore, the community is also involved in every decision making (Gani, 2014; Niswaty, Juniati, Darwis, Salam, \& Arhas, 2019; Tahir, 2016)

Community participation in each of these decision-making makes it possible for public service providers to be more responsive. The main thing that becomes an indicator that public service providers have been responsive to the community is the emergence of novelty or service innovation (Ayu, Niswaty, Darwis, \& Arhas, 2019). The concept of innovation has not yet been maximally developed in the public sector. This is because most public sector organizations are less challenged, because they are in a non-competitive climate, and do not even feel problematic in terms of their survival. So, it is natural that the concept of innovation is less developed in the public sector. However, changes that occur in the process of public administration require many other things to change (Mirnasari \& Suaedi, 2013).

The government was formed thus not to serve itself but to serve the community and create conditions that allow each member of the community to develop their abilities and creativity in order to achieve progress together (Rasyid, 1998). Meanwhile, (Moenir, 2000; Saggaf, Salam, Kahar, \& Akib, 2014) interpreting public services are activities carried out by a person or group of people on the basis of material factors through certain systems, procedures, and methods in an effort to meet the interests of others in accordance with their rights. A group of people who provide these services is the government bureaucratic apparatus. 


\section{Jurnal Administrare: Jurnal Pemikiran Ilmiah dan Pendidikan Administrasi Perkantoran Volume 6 Number 2 July- December 2019. Pages 131-136}

In an effort to realize maximum public services in South Sulawesi Province, one of the policies that were launched is the implementation of one-stop integrated service-based (Peraturan Menteri Dalam Negeri No. 24 Tahun 2006 tentang Pedoman Penyelenggaraan Pelayanan Terpadu Satu Pintu, 2006). In principle, this policy is the implementation of licensing or non-licensing services, the process of which starts from the application to the stage of issuance or issuance of a document carried out at one door so as to create public services that are fast, cheap, easy, transparent, certain, and affordable.

\section{METHOD}

This research uses a qualitative approach with the type of analytical descriptive research that aims to describe the facts about public services in the Investment Office and the One-Stop Integrated Service (DPMPTSP) of South Sulawesi. Data collection techniques in this study are observation, in-depth interviews, and documentation. Observations in the study were conducted in order to see firsthand the conditions in the field, both the research environment and the informants to be interviewed. The in-depth interviews were conducted with various informants, including the Head of the Department and the Integrated Licensing Services DPMPTSP South Sulawesi. The documentation technique used in this study is the voice recorder and image capture of the study site and the informants interviewed using mobile phones. This research was conducted at the DPMPTSP South Sulawesi located at Jalan Bougenville No. 5 Makassar. Data analysis techniques used are data reduction, data presentation, and drawing conclusions.

\section{RESULT AND DISCUSSION}

Public services are all forms of services both in the form of public goods and public services which in principle are the responsibility and are carried out by government agencies at the Central, regional, and within the State-Owned Enterprises or Regional-Owned Enterprises, in the context of implementing the provisions of the regulations legislation. Public services in this study refer to the view of (Parasuraman, 2003) that good public services include five things: tangibles, reliability, responsiveness, assurance, and empathy.

\section{Tangibles}

Basically the tangibles contained in DPMPTSP South Sulawesi are sufficient, as evidenced by the physical facilities it has. The facilities are: meubler; office stationery; computers and printers; server, LAN network plus Wifi; Scanner; CCTV; LCD Projector; Filing cabinet; Queue and Touchscreen Information Machines, data storage devices (database); Generator set; Cleanliness facilities; and Beauty Facilities. As for infrastructure, DPMPTSP South Sulawesi has a service security room; meeting/meeting room; service room; special disability service room; guest waiting room, nursing room for seniors and seniors; complaint room, electrical installation, telecommunications equipment; server room and workspace; archive/documentation storage space; control system room and data entry room; special disability entrance platforms; and banks and parking areas. 


\section{Reliability}

In terms of reliability, the services promised immediately and satisfactorily to the community are classified as very good. Public satisfaction with licensing services in DPMPTSP South Sulawesi is an average of 2.78, with an average expectation of 3.63. Thus, the IKM of 81.71 is classified in category A (Very Good). In terms of services promised, South Sulawesi DPMPTSP sets the duration of service time for licensing and non-licensing services. The following are services in several SKPD within the scope of DPMPTSP South Sulawesi:

Table 1. Regional Work Unit Services in South Sulawesi DPMPTSP

\begin{tabular}{clll}
\hline No. & Name Regional Work Unit Service & \multicolumn{1}{c}{ Type of Service } & \multicolumn{1}{c}{ Duration } \\
\hline 1 & Capital investment & $\begin{array}{l}\text { Licensing and non- } \\
\text { licensing }\end{array}$ & $1-3$ days \\
\hline 2 & Cooperatives \& SMEs & Licensing & $3-7$ days \\
\hline 3 & Social & Non-Licensing & $1-5$ days \\
\hline 4 & Maritime Affairs and Fisheries & Licensing & $1-3$ days \\
\hline 5 & $\begin{array}{l}\text { Transportation, Communication, and } \\
\text { Information }\end{array}$ & $\begin{array}{l}\text { Licensing and non- } \\
\text { licensing }\end{array}$ & $3-5$ days \\
\hline 6 & Animal Husbandry and Health & Licensing & $1-2$ days \\
\hline 7 & Employment & Licensing & 1 day \\
\hline 8 & Public Works & Non-Licensing & 5 days \\
\hline 9 & Energy and Mineral Resources & $\begin{array}{l}\text { Licensing and non- } \\
\text { licensing }\end{array}$ & $3-7$ days \\
\hline 10 & Health & $\begin{array}{l}\text { Licensing and non- } \\
\text { licensing }\end{array}$ & $3-7$ days \\
\hline 11 & Education & Non-Licensing & $1-2$ days \\
\hline 12 & Forestry & $\begin{array}{l}\text { Licensing and non- } \\
\text { licensing }\end{array}$ & $3-7$ days \\
\hline 13 & Living environment & $\begin{array}{l}\text { Licensing and non- } \\
\text { licensing }\end{array}$ & $3-7$ days \\
\hline 14 & Food security & Non-Licensing & 7 days \\
\hline 15 & Industry and Trade & Non-Licensing & $1-3$ days \\
\hline 16 & Plantation & Licensing & $5-7$ days \\
\hline 17 & Spatial & $\begin{array}{l}\text { Licensing and Non- } \\
\text { Licensing }\end{array}$ & 7 days \\
\hline 18 & National Unity and Politics & Non-Licensing & 1 day \\
\hline 19 & Research & Licensing & 1 day \\
\hline 20 & Culture and Tourism & Licensing & $1-3$ days \\
\hline Source DPMPTSP Sulawi Selan & &
\end{tabular}

Source: DPMPTSP Sulawesi Selatan, 2018

\section{Responsivensess}

Furthermore, responsiveness, namely the desire of staff to help customers and provide services with responsiveness. Responsiveness can also mean as a response or alertness of employees in helping customers or recipients of services and provide services that are fast and 


\section{Jurnal Administrare: Jurnal Pemikiran Ilmiah dan Pendidikan Administrasi Perkantoran Volume 6 Number 2 July- December 2019. Pages 131-136}

professional. The responsiveness of employees in South Sulawesi DPMPTS can be said to be already good, although of course there are still service users who feel lacking, ie sometimes employees are still found discussing other matters outside of their work, while the seats for service users in front of him are empty (can be occupied by service users another). Based on public satisfaction survey data in 2017, related to this responsiveness, there are service user opinions that sometimes employees do not contact immediately to the PIC submission of documents if there is a lack of permit application data. That is, the responsiveness in South Sulawesi DPMPTSP is still a separate record to be even better changes going forward.

\section{Assurance}

The insurance referred to here is not a guarantee of money or capital, but a guarantee that includes the ability, courtesy, and trustworthiness of the staff, free from danger, risk or doubt. The guarantee given by employees to service users in DPMPTSP South Sulawesi shows ability, courtesy and trustworthiness. The higher the assurance provided, the more the public or service users feel that employees have a good ability, courtesy, and trustworthiness.

\section{Empathy}

The last dimension in assessing good public services, namely empathy, that is, a sense of understanding and care includes the ease of making good communication relationships, and understanding the needs of customers. Empathy in-licensing and non-licensing services in DPMPTSP South Sulawesi can be categorized as good because there are several facilities that allow everyone to get the same service, for example, facilities for people with disabilities and service facilities for seniors, pregnant and lactating women. This shows that the empathy created in DPMPTSP South Sulawesi is in line with the promise of service that is to give the best service wholeheartedly to all people who ask for service.

\section{Discussion}

The implementation of public services now and in the future in order to achieve World Class Government in 2025 (Bureaucratic Reform Design, 2014), is not an ordinary job, but it must be an extraordinary job by accelerating through various new breakthroughs. Public service innovation is accelerating to make a breakthrough to become a solution to improve the quality of public services that is closer to the expectations of the community.

The Government of South Sulawesi continues to provide the best public services to the community. This can be seen from the vision and mission that was launched, namely "The Province of South Sulawesi Best Service and Realization of Investment in Indonesia". To achieve this vision, there are 4 (four) missions carried, namely: improving the Quality of Investment Services. To meet the satisfaction of the services received by investors is a strategic step that will be taken by the regional government, not only by BKPMD but all those related to investment activities in this area. To provide satisfying services, one of which is through the creation of services that are pro-active, integrated and comprehensive; Increase Investment Attractiveness and Interest. The attractiveness of investment will be good if it is accompanied by the formulation of strategic, valid and realistic investment planning policies, spatial planning 
and appropriate and consistent investment mapping followed by rapid, precise and realistic and economical information dissemination, promotion and information to be implemented. One important thing is not only the development of a number of investment opportunities but also in the form of regulations that provide facilities and incentives for investors; optimize Innovation and Infrastructure Support. Opportunities to increase the realization of open-investment are very wide through the development of innovations in the form of diversification of regional superior products, the availability of adequate physical infrastructure, including optimizing the strategic role of the Makassar Industrial Area (KIMA) in the framework of developing South Sulawesi investments as a whole; Building an Extensive Investment Network. The investment network needed to increase investment realization is more open to access to broad investment to find a number of opportunities for partnership (partnership) both with the business world and with government agencies and non-profits at home and from abroad.

Table 2. Matrix of Public Services at DPMPTS South Sulawesi

\begin{tabular}{|c|c|c|c|c|c|}
\hline & \multicolumn{5}{|c|}{ Pelayanan Publik } \\
\hline & Tangibles & Reliability & Responsiveness & Assurance & Empathy \\
\hline $\begin{array}{l}\text { Service } \\
\text { Intent }\end{array}$ & $\begin{array}{l}\text { Everything that } \\
\text { is tangible such } \\
\text { as: physical } \\
\text { facilities, } \\
\text { equipment, } \\
\text { employees, and } \\
\text { means of } \\
\text { communication }\end{array}$ & $\begin{array}{l}\text { Provide the } \\
\text { promised } \\
\text { service } \\
\text { immediately } \\
\text { and } \\
\text { satisfactorily }\end{array}$ & $\begin{array}{l}\text { Helping service } \\
\text { users and } \\
\text { providing } \\
\text { services } \\
\text { responsively }\end{array}$ & $\begin{array}{l}\text { Ability, } \\
\text { politeness, and } \\
\text { trustworthiness } \\
\text { that employees } \\
\text { have }\end{array}$ & $\begin{array}{l}\text { Understand } \\
\text { and care } \\
\text { for the } \\
\text { needs of } \\
\text { service } \\
\text { users }\end{array}$ \\
\hline $\begin{array}{l}\text { Service } \\
\text { Category }\end{array}$ & Very good & Good & $\begin{array}{l}\text { Good (but there } \\
\text { are still service } \\
\text { users who feel } \\
\text { they are } \\
\text { lacking) }\end{array}$ & Good & Good \\
\hline $\begin{array}{l}\text { Basic } \\
\text { theoretical } \\
\text { arguments }\end{array}$ & \multicolumn{5}{|c|}{$\begin{array}{l}\text { Schuler (1997), innovation quality means providing service that consistently } \\
\text { follows all dimensions of quality in one single effort. Goetsch \& Davis (2006), the } \\
\text { quality of public services must be oriented to the expectations desired by service } \\
\text { users. Parasuraman (2003), the quality of public service innovation regarding how } \\
\text { far the difference between reality and expectations of service users for the services } \\
\text { they receive, if reality exceeds what is expected then the service can be said to be } \\
\text { quality and vice versa. }\end{array}$} \\
\hline
\end{tabular}

\section{CONCLUSION}

The results showed that basically, tangible in DPMPTSP South Sulawesi was adequate, as evidenced by the physical facilities it possessed. In terms of reliability, the ability to provide the promised services immediately and satisfactorily to the public is classified as very good. Furthermore, regarding the responsiveness of employees in South Sulawesi DPMPTS it can be 
136 Jurnal Administrare: Jurnal Pemikiran Ilmiah dan Pendidikan Administrasi Perkantoran
Volume 6 Number 2 July- December 2019. Pages 131-136

said to be already good, although of course there are still service users who feel inadequate, ie sometimes employees are still found discussing other things outside of their work. Regarding assurance at DPMPTSP, South Sulawesi shows that the community or service users feel that employees have the ability, courtesy and trustworthiness. And, regarding empathy in-licensing and non-licensing services in South Sulawesi DPMPTSP can be categorized as good, as evidenced by several facilities that allow everyone to get the same service, such as facilities for the disabled (disabled) and service facilities for seniors, pregnant women, and breastfeeding.

\section{REFERENCES}

Ayu, A., Niswaty, R., Darwis, M., \& Arhas, S. H. (2019). Applying the principles of Good Governance in the Efforts of Guiding Out-of-School Children at Social Service Offices Takalar Regency. Jurnal Office, 5(2), 51-58.

Gani, F. S. (2014). Respon Masyarakat Terhadap Kinerja Pelayanan Publik Di Kantor Kecamatan Pinogaluman. Jurnal Ad'ministrare: Jurnal Pemikiran Ilmiah dan Pendidikan Administrasi Perkantoran, 1(1), 62-71.

Goetsch, D. L., \& Davis, S. (2006). Quality management: Introduction to total quality management for production, processing, and services. Prentice Hall.

Mirnasari, R. M., \& Suaedi, F. (2013). Inovasi Pelayanan Publik UPTD Terminal PurabayaBungurasih. Jurnal Kebijakan dan Manajemen Publik, 1(1), 71-84.

Moenir, A. S. (2000). Public Service Management in Indonesia. Jakarta: Bumi Aksara.

Niswaty, R., Juniati, F., Darwis, M., Salam, R., \& Arhas, S. H. (2019). The Effectiveness of Leadership Functions Implementation in The Makassar Departement of Manpower. JPBM (Jurnal Pendidikan Bisnis dan Manajemen), 5(1), 1-10.

Parasuraman, R. (2003). Neuroergonomics: Research and practice. Theoretical Issues in Ergonomics Science. https://doi.org/10.1080/14639220210199753

Peraturan Menteri Dalam Negeri No. 24 Tahun 2006 tentang Pedoman Penyelenggaraan Pelayanan Terpadu Satu Pintu. (2006). Kementerian Dalam Negeri.

Rasyid, R. (1998). Desentralisasi dalam menunjang pembangunan daerah dalam pembangunan administrasi di Indonesia. Jakarta: Pustaka LP3ES.

Saggaf, S., Salam, R., Kahar, F., \& Akib, H. (2014). Pelayanan Fungsi Administrasi Perkantoran Modern. Jurnal Ad'ministrare, 1(1), 20-27.

Schuler, C. (1997). A quality of service concept for wireless ATM. IEEE ATM Workshop 1997. Proceedings, 381-390. IEEE.

Tahir, N. (2016). Motivasi Kerja Pegawai dalam Pelayanan Publik di Sekretariat Pemerintah Daerah Kabupaten Takalar. Jurnal Ad'ministrare: Jurnal Pemikiran Ilmiah dan Pendidikan Administrasi Perkantoran, 3(2), 1-10. 